\title{
Not what Parliament intended: the case for reviewing fines for term-time holidays
}

Andrew Defty, University of Lincoln

Educational Review, volume 70, number 5, 2018, pp.535-547.

\begin{abstract}
In 2013, changes to the regulations regarding school absences meant that head teachers could no longer authorise term-time holidays. As a consequence of this parents who wish to take their children on holiday during term-time are now liable for a fixed penalty notice. This policy has been the subject of a number of legal challenges most notably in a case heard by the UK Supreme Court in 2017 which upheld local authorities' power to impose fines for term-time holidays. This article examines the legal and political arguments around the extension of penalty notices for term-time holidays. It reviews the various challenges to the policy, focusing on the Supreme Court judgment. The article goes on to make an alternative case for review of this policy based on the manner in which the regulations were changed, arguing that the Secretary of State for Education exceeded his powers by changing attendance regulations without parliamentary approval and in a way that parliament had not intended when legislation governing the use of penalty notices was passed in 2003.
\end{abstract}

In 2013, the Secretary of State for Education, Michael Gove, changed the regulations governing the recording of school absences. Mr Gove removed headteachers' power to authorise up to ten days absence in any school year to allow a child to go on holiday. The effect of this change was to make parents who take children out of school for holidays liable to a fixed-penalty notice under legislation designed to combat truancy, which had been introduced by the Labour government in 2003. The changes in the regulations have led to a significant increase in the number of penalty notices issued (Long and Bolton, 2017). The application of penalty notices to term-time holidays has been unpopular amongst parents and teachers (YouGov, 2014; YouGov, 2017; Parker, 2017), and has prompted a number of legal challenges. Most notably, in 2017 the UK Supreme Court upheld a penalty notice issued by Isle of Wight Council to a parent, Jon Platt, who refused to pay a fine after taking his daughter out of school for a holiday. The Court ruled that any unauthorised absence, no matter how small, and irrespective of the child's level of attendance prior to the absence, could lead to criminal liability. 
This article examines the legal and political arguments around the imposition of fines for term-time holidays. It begins by examining the legal obligation to ensure that children attend school and the introduction, in 2003 , of penalty notices to combat truancy. It goes on to examine the various challenges to the use of penalty notices to penalise parents who have taken their children out of school for holidays, focusing in particular on the Supreme Court's judgment in the Platt case. The article concludes by setting out the grounds for a review of the application of fines for term-time holidays based on an examination of the manner in which the regulations were changed. The purpose here is not to challenge the Supreme Court's judgment in the Platt case, although it is argued that the judgment was in a number of respects anomalous. Rather it is argued that the manner in which the regulations were changed, through the use of a Statutory Instrument which was not subject to parliamentary scrutiny, leaves scope for a further review of this policy on the basis that the Secretary of State exceeded his powers. It is argued that, by changing the regulations regarding what can be constituted as an authorised absence, Mr Gove removed headteachers' discretion regarding the authorisation of absences and changed the meaning of the Anti-Social Behaviour Act in a way which parliament did not intend when the legislation was passed in 2003.

\section{The legal basis for penalty notices for school absences}

The legal basis for imposing penalties for school absences lies in the 1996 Education Act which places a legal obligation on parents to ensure their child attends school. Section 444 of the Act states that: 'If a child of compulsory school age who is a registered pupil at a school fails to attend regularly at the school, his parent is guilty of an offence'. There are in fact two offences under section 444 . The first (s.444 (1)) relates to parents who fail to ensure that their child attends school regularly. If convicted of this offence parents can be subject to a fine of up to $f 1000$. A further more serious offence (s.444 (1A)) was added in 2001 for circumstances in which a parent fails to deal with persistent truancy. Parents who know that their child is not attending school regularly, presumably because they have already been informed about this, and subsequently fail to ensure attendance, can be subject to a fine of $£ 2500$ or up to three months imprisonment. The legislation does provide parents with a number of statutory defences against prosecution to allow for absence as the result of 'sickness or any unavoidable cause' and in the case of knowingly allowing a child not to attend, a defence of 'reasonable justification' for their failure to ensure attendance may be considered. Crucially, however, the Act does not define what constitutes regular attendance. The only attempt to quantify regular attendance in the 1996 Act related to the very specific circumstances of a child of no fixed abode, for whom a defence against prosecution for non-attendance may be made if the 
child 'has made at least 200 attendances during the period of 12 months ending with the date on which the proceedings were instituted' (Education Act 1996, s.444).

While the Education Act 1996 made an offence of failing to ensure a child's regular attendance at school, the application of fixed-penalty notices for school absences was introduced by the Labour government as part of the Anti-Social Behaviour Act 2003. This made it easier for local authorities to punish parents by allowing for a penalty notice to be issued in respect of failure to ensure regular attendance at school. Penalty notices allow individuals to avoid criminal conviction and a potentially more significant penalty by agreeing to accept a small fine. Although penalty notices had been widely used, primarily to deal with motoring offences, Labour significantly expanded their use to deal with a wide-range of other offences including public order offences, environmental crimes and truancy. Under the Anti-Social Behaviour Act parents could avoid a section 444 conviction if they agreed to pay a fixed penalty of $£ 60$ increasing to $f 120$ if not paid within 21 days. Penalty notices can be issued by the local authority, a headteacher or the police. The Anti-Social Behaviour Act also introduced various other measures designed to support or require parents to deal with misbehaviour and irregular attendance including parenting contracts which are signed agreements between parents and schools, and parenting orders, which can be imposed on parents by the courts (Anti-Social Behaviour Act 2003, part 3).

While the Anti-Social Behaviour Act relied on the definition of an offence provided in section 444 of the 1996 Education Act it offered no further clarity as to what might constitute regular attendance. Moreover, the legislation provided for considerable freedom in the drafting of regulations regarding the form and content of the penalty notice, including the amount and the circumstances in which it might be applied. The details of the policy including an exemption for term-time holidays, and subsequent removal of this exemption, were not set out in the legislation but were introduced in a series of regulations introduced over subsequent years. These allowed for considerable discretion in the application of the policy. The form of the penalty notices, for example, were set out in a regulation introduced in 2007, which allowed local education authorities to draw up codes of practice with regard to the consistent application of penalties within a local authority area, but allowed for differential practice between local authorities (Education (Penalty Notices) Regulations, 2007). The exemption for term-time holidays was included in regulations introduced in 2006 which stated that pupils could be granted leave of absence to go away on holiday but that 'except in exceptional circumstances' this would not amount to more than ten days leave of absence in one school each year (Education (Pupil Registration Regulations, 2006). This exemption was changed by new regulations introduced by Education Secretary, Michael Gove, which came into force on 1 
September 2013 (Education (Pupil Registration) (Amendment) Regulations, 2013). This tightened up the rules regarding when headteachers could authorise an absence, by stating that leave of absence would only be granted in 'exceptional circumstances' and that this would no longer include up to ten days a year for a family holiday. As a result absence for holidays would now be classed as an unauthorised absence. This left parents who take their children out of school for holidays open to the imposition of a fixed-penalty notice under the Anti-Social Behaviour Act. Failure to pay could lead to prosecution under section 444 of the Education Act 1996.

In the period since 1996 there was a gradual tightening up of the law relating to school attendance and an erosion in the power of headteachers to apply discretion in this area. While the 1996 Education Act imposed a legal obligation on parents to ensure their child attends school, subsequent changes have provided for tougher penalties for failing to meet this obligation, as well as making it easier for local authorities to punish parents. There are, however, a number of anomalies in relation to the law in this area. While the law clearly imposes an expectation that children should regularly attend school, neither the 1996 legislation nor any of the subsequent regulations, have sought to define what constitutes regular attendance, effectively leaving it up to the courts to arbitrate on this. Moreover, while headteachers retain a broad general autonomy to authorise 'leave' and a particular authority to do so in relation to illness, to allow for religious observance or for any other 'unavoidable cause' (Education Act 1996), since the introduction of the 2013 regulations headteachers no longer have discretion to apply the rules in relation to absences for term-time holidays. Finally, many of the regulations relating to attendance policies particularly in relation to the imposition of penalty notices for non-attendance are not included in primary legislation but have been added to existing legislation by the Secretary of State for Education through a process which has involved very little, if any, parliamentary scrutiny. As will be argued below these gaps leave scope for review of this policy particularly in relation to its application to term-time holidays.

\section{Challenging penalty notices for term-time absence}

The introduction of penalties for term-time holidays has generated considerable opposition and has, perhaps inevitably, been challenged in the courts. The introduction of penalty notices for school absences not only made it easier for local authorities to punish parents but also shifted responsibility for initiating legal proceedings onto parents wishing to contest the notice. Schools and local authorities wishing to punish parents for failing to ensure their child attends school no longer have to undertake costly legal proceedings, but this is the only option for parents who wish to challenge a penalty notice. Perhaps not surprisingly while there has been a steep increase in number of penalty notices issued, particularly since 2013 (Long \& Bolton, 2017), most parents have chosen to pay the 
penalty rather than risk the potentially more costly option of challenging a penalty notice in the courts. Consequently while there has been considerable opposition to the policy amongst parents' groups, not least on the grounds that the policy discriminates against less well-off parents, challenging the policy in the courts has been limited to those with the resources to do so.

In 2014 a campaign for judicial review of the policy was organised by a group of parents under the banner, Parents Want a Say. The campaign was supported by the Liberal Democrat MP, John Hemming, and was based on the argument that penalty notices for term-time holidays represented a breach of the right to a family life, which is protected under the Human Rights Act. Parents Want a Say also argued that the policy particularly discriminated against less well-off parents who could not afford to take family holidays during school holiday periods when prices are at a premium. This argument was reinforced by reports that the policy was having little impact on better-off parents who had simply begun to factor the $\mathrm{f} 60$ penalty into the cost of a holiday. It was also argued that the policy had little basis in educational research and was being used by local authorities as a means of generating revenue (Griffiths, 2014a).

The claim that local authorities use penalty charges as a means of revenue generation have been made in relation to the application of other fixed-penalty notices such as parking charges. A 2013 inquiry by the House of Commons transport select committee found that although the setting of parking charges in order to raise revenue was illegal, 'there is a deep-rooted public perception that local authorities view parking enforcement as a cash cow' and that 'there is a very strong case for more transparency about how funds are spent' (Transport Committee, 2013). The increase in the use of penalty notices in relation to term-time absences and in particular the disparities in the application of penalty notices across local authority areas has prompted similar concerns. In March 2018, the BBC reported that penalty notices for unauthorised school absences had generated f24million for local authorities in England and Wales. It also revealed considerable disparities between local authorities in the application of the policy (Cawley, 2018).

While Parents Want a Say sought to crowdfund support, the costs involved in mounting a legal challenge have meant that the most significant challenges have come from those who have been able to pay. In 2014, The Sunday Times reported that 'a high flying executive' (a banker from JP Morgan), was about to mount a test case, by refusing to pay a penalty notice issued by his local authority, Essex County Council, when he took his three children out of school to attend a memorial service in the USA for their great-grandfather. This case did not involve a term-time holiday but related to the headteacher's refusal to authorise an absence on the grounds that attending a relative's memorial service was not considered an exceptional circumstance (Griffiths, 2014b). 
Interestingly, this decision was based on an assessment of the attendance level of the children involved and although all three children attended the same primary school the penalty notice was only issued in relation to one of the children who had an attendance of $87 \%$. The family, who were represented by lawyers provided by Liberty, argued that the prosecution was a breach of their human rights, in particular the children's right to a family life. The case was eventually withdrawn by Essex County Council when the family emigrated to the United States. Although the local authority maintained that the school had followed their attendance policy to the letter, it was not considered in the public interest to pursue a prosecution once the family had left the country (ITV News, 2014).

The most significant challenge to fines for term-time holidays came from Jon Platt, a businessman from the Isle of Wight, who was taken to court by his local authority after taking his daughter on a holiday to Disney World in Florida in April 2015, causing her to miss seven days of school. Platt's request to take his daughter out of school was declined by the headteacher of her primary school. Following the unauthorised absence, Platt was issued with a $f 60$ penalty notice, which was increased to $f 120$ after 28 days. On failing to pay the fine, Platt was prosecuted in the Magistrates court. Platt's defence rested on the question of what constituted regular attendance and focused on his daughter's attendance record to date. It was argued that Platt's daughter, who had an attendance rate of $95 \%$ prior to the holiday and $90 \%$ afterwards, could not be seen as not attending school regularly. His case was supported by the council's own policies which defined an attendance rate of between $90 \%$ and $95 \%$ as satisfactory. The Magistrates decided there was no case to answer and Platt was found not guilty. When the local authority appealed the case to the High Court they also found in Platt's favour, agreeing that the child's level of attendance prior to the unauthorised absence should be taken into consideration.

With the support of the Department for Education, the Isle of Wight Council appealed again, to the UK Supreme Court. The case was heard in January 2017 and the judgement delivered in April. The Supreme Court overruled the decisions of the lower courts and found that Mr. Platt had committed an offence under section 444 of the 1996 Education Act. The case was returned to the Magistrates court where Mr. Platt was given a 12 month conditional discharge and ordered to pay costs (Supreme Court, 2017; Coughlan, 2017).

The Supreme Court judgement once again focused on the meaning of 'fails to attend regularly' in section 444 of the Education Act 1996. Unlike the lower courts the Supreme Court did not, however, seek to quantify regular attendance but sought instead to offer a definition of 'regularly' which was not dependent upon a calculation of previous attendance. In seeking to determine what Parliament 
meant when the legislation was passed, the justices argued that there are three possible meanings of regularly:

(a) Evenly spaced, as in "he attends Church regularly every Sunday"; (b) sufficiently often, as in "he attends Church regularly, almost every week"; or (c) in accordance with the rules, as in "he attends Church when he is required to do so" (Supreme Court, 2017, para.1).

The first definition it was argued could not apply. If 'regularly attend' meant attending at evenly spaced intervals 'it would enable attendance every Monday to count as regular even though attendance every day of the week is required.' The court observed that the second definition of 'regularly attend' as sufficiently frequently 'might well be the meaning assumed by many people at first reading' and appears to be the definition applied in previous judgments. This definition it suggested 'is what we mean when we talk about a person being a regular at the pub or a regular at church services'. But cannot apply to schools because 'attendance at the pub or at church is not compulsory.' In a somewhat circular argument the judges also argued that this definition would lead to a debate over the meaning of 'sufficient'. Without quantifying what level of attendance is considered sufficient: 'Over what period is the sufficiency of attendance to be judged? How much is sufficient?' Which was, of course, precisely the argument made by Mr. Platt's defence team in relation to the term 'regular' (Supreme Court, 2017, para.30-32).

The Court concluded that the only possible definition of regularly in the case of school attendance, must be attendance on every occasion when it is expected. According to this definition regularly means 'in accordance with the rules' and as a result 'a single missed attendance without leave or unavoidable cause could lead to criminal liability.' The Court argued that there are 'many examples where a very minor or trivial breach of the law can lead to criminal liability', such as, for example, stealing a milk bottle, driving at 31 miles per hour in a 30 miles per hour zone, or failing to declare imported goods over the permitted level (Supreme Court, 2017, para 32-3).

Although the Court focused on the narrow question of the meaning of regular attendance, in arriving at its judgement it did also give consideration to wider arguments regarding the impact of school absence. The Court, for example, accepted the Government's argument 'that there is a clear statistical link between school attendance and educational attainment' (Supreme Court, 2017, para.40), a claim which has been contested in a number of studies (Dağli, 2018; Santry, 2016). It also argued that absence was disruptive not just to the individual child's education but also to other children either by undermining the value of group learning or by taking up teachers' time through 
the allocation of additional or replacement work. Finally, it concluded that it was, in principle, unacceptable for parents to disregard school rules relating to attendance, concluding:

This is not an approach to rule-keeping which any educational system can be expected to find acceptable. It is a slap in the face to those obedient parents who do keep the rules, whatever the cost of inconvenience to themselves (Supreme Court, 2017, para.41).

The decision was, no doubt, a relief for the government. Interestingly, however, the government's response stressed that the courts had asserted the rights of headteachers to decide when absences could be authorised, with the Prime Minister for example, observing that, 'It's right that the individual head teacher has that flexibility to make that decision' (Coughlan, 2017). This is at best a misunderstanding of the case, which did not focus on the question of who has the right to authorise absences but the circumstances in which authorisation may be allowed. In fact, the 2013 regulations had removed headteachers' flexibility in this area, by preventing them from allowing up to ten days absence a year for a family holidays. Indeed, the Supreme Court's decision to apply a narrow definition of 'regularly attend' to mean on every occasion on which it is expected, rather than for example, most of the time, also appears to limit headteachers' discretion in this area.

\section{Parliamentary intent and the case for review of penalty notices for term-time holidays}

Legal challenges to the policy of imposing penalty notices for school absences have focused on the potential for the law to infringe human rights and the extent to which existing levels of attendance should be considered when authorizing absence. While the withdrawal of the case involving Essex County Council means that the human rights argument was never tested in the courts, the Supreme Court judgment in the Platt case does provide a definitive meaning for the parents' duty to ensure regular attendance as set out in the Education Act 1996. The door to further challenges based on a child's level of attendance is now firmly closed.

There may, however, be scope for a further review of this policy based on consideration of the process whereby changes were made to the regulations to allow for the imposition of penalty notices for parents who take their children out of school for term-time holidays. This argument is not based on interpretation of the meaning of the law, but on whether the way in which the law is currently being applied is in keeping with what Parliament intended when penalty notices for school absences were introduced in 2003.

In the UK system, it is the role of the courts to interpret the law as passed by Parliament. The courts often refer to the intention of Parliament when reaching their judgments. If legislation is clear, then 
appeals to parliamentary intent are rarely necessary. However, if the construction of legislation is ambiguous or obscure then the courts may look back at parliamentary material in order to determine what was intended when the legislation was passed (Ekins, 2012). The role of the courts in interpreting the intentions of Parliament when a piece of legislation was passed has generated considerable debate. Critics of this approach argue that there is no such thing as legislative intent, not least because Parliament does not have one mind. Members of Parliament, sitting in two Houses may intend different things when debating and voting on a piece of legislation and any analysis of parliamentary material which focuses on the views of individual parliamentarians cannot be used to determine the views of parliament as a whole (Craig, 2004; Laws, 2017). Defenders of the construction of legislative intent, argue that while individual parliamentarians may have different views, legislation arises from a majority vote on a particular policy proposal or plan. If the resulting legislation is not clear, the intentions may be discerned through careful examination of the proposals as put to Parliament (Ekins, 2012; Allan, 2004). Moreover, while parliamentary intent may at times prove elusive, it may at least be possible to determine what Parliament did not intend when passing a piece of legislation.

In arriving at their judgement in the Platt case, the Supreme Court was primarily concerned with seeking to establish what Parliament meant by 'attend regularly' when the Education Act was passed in 1996. In their judgement the Court stated that, in reference to the three possible meanings of regularly attend, their aim was to decide, 'which was the meaning intended by Parliament when enacting section 444 (1)' (Supreme Court, 2017, para.29). Parliament is invoked elsewhere in the Supreme Court's judgment, for example, in the assertion that 'Parliament is unlikely to have found it acceptable that parents could take their children out of school in blatant disregard of school rules' (para.41) and that the provision regarding an acceptable level of attendance for children of no fixed abode, 'illustrates that when Parliament wishes to indicate what, in its view, is sufficiently frequent, it can and does do so' (para. 36).

However, what is striking in this case is not that the Supreme Court focused on the meaning of regular attendance in the Education Act 1996, but that it gave no consideration at all to what Parliament intended when penalty notices for school absence were introduced as part of the AntiSocial Behaviour Act 2003. As noted above, while the 1996 Act imposes a responsibility on parents to ensure that their children attend school, it is the 2003 Act which allows local authorities to issue penalty notices for failing to meet this obligation and it was as a consequence of failing to pay a fine under this piece of legislation that Mr. Platt was prosecuted. 
This question is complicated by the fact that the extension of penalty notices to cover term-time holidays was not included in either the 1996 or the 2003 legislation but was introduced as a consequence of a piece of delegated legislation, or Statutory Instrument, which Parliament did not have the opportunity to debate. Statutory Instruments are mechanisms which confer powers on Ministers or other public bodies in relation to the operation and implementation of particular Acts of Parliament. This might include the provision of detailed regulations or setting the level of charges or fees which might change over time. Crucially, Statutory Instruments must relate to a particular Act of Parliament and must not go beyond what is allowed for in the parent Act (Byrne, 1976; Fox and Blackwell, 2014).

Statutory Instruments come in a number of different forms and are not subject to the same level of scrutiny as Acts of Parliament. Affirmative instruments require specific approval by both Houses of Parliament before coming into effect. Negative instruments come into effect automatically unless either House seeks to annul them. These are, by far, the most numerous category of Statutory Instrument. There is a third category which do not require any parliamentary approval at all, but these are really for information and comprise a very small proportion of Statutory Instruments in each parliamentary session (Byrne, 1976; Rogers and Walters, 2015). Statutory Instruments are rarely debated in the chamber but are considered by a Joint Committee on Statutory Instruments. The committee, however, does not consider every Statutory Instrument in detail, has no formal powers to reject an instrument and it is possible for instruments to be passed before the committee has considered them (Norton, 2013).

Perhaps not surprisingly, the opportunity to avoid detailed parliamentary scrutiny means that the use of Statutory Instruments has become increasingly popular with governments. The number of Statutory Instruments in each parliamentary session has more than doubled in the last thirty years, with well over 3,000 Statutory Instruments now made in each calendar year (Rogers \& Walters, 2015; House of Lords Constitution Committee, 2016). Critics have pointed to the 'explosion' in use of Statutory Instruments as evidence of a decline in the extent and quality of legislative scrutiny (Korris, 2011; Fox and Korris, 2010). It is not just the number, but also the length of Statutory Instruments that has increased, so that the number of pages of delegated legislation passed in a parliamentary session now significantly exceeds the number of pages of primary legislation. This has led to the suspicion that governments are seeking to present primary legislation in skeleton form so that the details can be added at a later date through the less arduous tabling of delegated legislation. In a report for the Hansard Society in 2010, Fox and Korris observed that there were often 'significant disparities between the content of the discussion at the primary legislation stage 
and the final content of delegated legislation' and as a result there is often 'a chasm between what MPs and Peers are led to believe they are voting for and what is actually delivered' (Fox and Korris, 2010). Similarly in 2016, a House of Lords Constitution Committee inquiry into the use of delegated legislation observed that:

Delegated powers in primary legislation have increasingly been drafted in broad and poorlydefined language that has permitted successive governments to use delegated legislation to address issues of policy and principle, rather than points of an administrative or technical nature (House of Lords Constitution Committee, 2016).

While the use of Statutory Instruments has become increasingly popular with governments, making changes to legislation through delegated or secondary legislation has provided a rich source for claims for judicial review on the basis that Ministers have exceeded their powers. This may be a particular problem if Statutory Instruments are introduced a long time after the parent Act, or if, for example, a Statutory Instrument seeks to make changes to a piece of legislation introduced by a previous government. If Statutory Instruments are used to make changes which go beyond what Parliament intended in the passage of a piece of legislation, Ministers leave themselves open to the charge that they are acting ultra vires, beyond their powers. Moreover, unlike primary legislation, Statutory Instruments can be subject to judicial review and, if it is decided that Ministers have exceeded their powers, can be overturned by the courts.

The principle that parents should ensure their children attend school regularly is established in primary legislation, the Education Act 1996; as is the power to apply penalty notices for failure to meet this obligation, the Anti-Social Behaviour Act 2003. However, as noted above, much of the detail regarding the application of these policies is set out in a series of Statutory Instruments which were not subject to parliamentary scrutiny. Most significantly, the regulations governing the authorization of absences, which underpins the 1996 parental obligation to ensure regular attendance, is almost entirely contained in secondary legislation (Education (Pupil Registration) Regulations, 2006). In some cases these Statutory Instruments are much more detailed than the legislation to which they relate. For example, the principle that penalty notices can be used to combat truancy is set out in skeleton form in a little over three pages of the Anti-Social Behaviour Act 2003, while the Statutory Instrument which puts flesh on these legislative bones runs to eight detailed pages (Education (Penalty Notices) Regulations, 2007). These regulations not only set out technical details such as the level of fines for penalty notices, but also such issues as who is authorised to impose and collect fines and the power of the Secretary of State to demand changes to local authority codes of conduct in relation to the issue of penalty notices. 
The application of penalty notices for term-time holidays came about as a result of a very short Statutory Instrument in 2013 (Education (Pupil Registration) (Amendment) Regulations 2013) which removed headteachers' discretion to allow for absence of up to 'ten school days for the purpose of a holiday.' This was a negative Statutory Instrument which Parliament did not seek to annul and was not therefore subject to parliamentary scrutiny or debate (Joint Committee on Statutory Instruments, 2013). Although this change related to the regulations governing pupil attendance included in a previous Statutory Instrument (Education (Pupil Registration) Regulations 2006), it also had the effect of changing the meaning of the Anti-Social Behaviour Act 2003, by expanding the boundaries of what constitutes an unauthorised absence. If there are grounds for challenging the Education Secretary's decision to change the regulations governing unauthorised absences, it will need to be shown that the effect of this change was not what Parliament intended when voting to support the expansion of penalty notices to cover school absences in 2003.

Although the Education Secretary's changes to the regulations regarding attendance were not subject to parliamentary scrutiny in 2013 , the issue of penalty notices for unauthorised absence was debated at length when the Anti-Social Behaviour Bill made its way through Parliament in 2003. There was considerable opposition, particularly from the Conservative benches, to the use of penalty notices for any form of school absence. Several MPs raised questions about the desirability and practicalities of making teachers responsible for imposing and collecting fines from parents. The Conservative shadow education spokesperson, Oliver Letwin, was particularly critical of 'the mindnumbing idea that teachers could hand out fixed penalty notices to the parents of children at their school' concluding that, 'I cannot imagine how the Home Secretary imagines that such a provision would be workable' (Hansard - Commons, 8 April 2003 col.152). The Conservative MP, John Bercow, now Speaker of the House of Commons, was critical of the 'breast-beating Home Secretary' who appeared to be legislating 'simply to feel better or to appeal to the Daily Mail or other tabloid newspapers' (Hansard-Commons, 8 April, 2003, col.195). Another Conservative MP, and former teacher, Liz Blackman, expressed 'grave concerns' about the notion that teachers would be responsible for imposing fines on parents (Hansard-Commons, 8 April 2003, cols.177-179), a view which was echoed by several members who felt it would damage the relationship between schools and parents. These included the Liberal Democrat MP, Annette Brooke, who observed that, 'it is incredibly undesirable for head teachers and teachers to impose fines for truancy: a separation is needed between enforcers and those who are trying to work with children and their families' (Hansard-Commons, 8 April 2003, col.185). 
On the more specific issue of whether penalty notices might be applied to parents taking their children on holiday during term-time there is no evidence that this was the government's intention and the issue was simply not discussed when the Anti-Social Behaviour Bill made its way through Parliament. The clear intention as outlined during the passage of the Anti-Social Behaviour Act, was that fixed-penalty notices were designed to deal with persistent and problematic truancy, and at no point was it suggested that they should be used for anything other than this. In introducing the Bill, the Home Secretary, David Blunkett, made it clear that part 3 of the Bill which dealt with penalty notices and parenting orders, 'relates to truancy' and referred, in particular, to the need to tackle 'the few parents whose behaviour is not only a terrible example to their children and others, but a disruption to the life and work of schools' (Hansard - Commons, 8 April 2003, col.144). The debate in the House of Commons centred on the notion that children who were playing truant were not under the supervision of anyone else and as a result truancy was seen a route into bad behaviour. The Labour MP, Ann Coffey, argued that the package of measures in the Bill were designed to help children from 'chaotic families', in order to 'keep those children from failing at school, turning to criminality and costing the state thousands in secure accommodation, youth custody and years in and out of jail' (Hansard-Commons, 8 April 2003, col.188). While the Home Office Minister, Bob Ainsworth responded to criticisms of the proposal by asking: 'What is the matter, in some circumstances, with head teachers and governing bodies approving specific members of staff to issue fixed penalty notices to deal with the problem of truancy?' (Hansard-Commons, 8 April 2003, col. ) The emphasis on penalty notices as a tool to deal with truancy was mirrored in the House of Lords, where the government spokesperson, Baroness Scotland, specifically and repeatedly referred to the policy as 'penalty notices for truancy.' (Hansard - Lords, 18 July 2003 col.1153; Hansard Lords, 17 September 2003 col.970-971).

Moreover, in response to concerns raised in both chambers about who would be responsible for issuing penalty notices, considerable emphasis was placed on the discretion which would be exercised by headteachers and others in the application of this policy. The government made clear that decisions about the application of the policy would be taken at a local level. The clear implication was not that the penalty notice would be applied in every case but that headteachers and education welfare officers would employ their judgement as to the seriousness of the case. The government's position was set out clearly by Baroness Scotland in the House of Lords:

We expect most fixed penalty notices for truancy to be issued by local authority education welfare officers, who also organise prosecutions for truancy. We believe that it is right to give head teachers and assistant head teachers, authorised by them, the power to do so. 
The decision whether to issue a penalty notice in an individual case will involve the making of a professional judgment, which we believe can be appropriately exercised by the senior management (Hansard - Lords, 18 July 2003 col.1153).

While there was considerable debate about the merits of allowing schools to issue penalty notices, with regard to the purpose of penalty notices for school absences, the intention of Parliament is clear. Penalty notices for school absences were included in the Anti-Social Behaviour Bill as a means of combating truancy. This was the clearly stated position of the government when presenting the Bill to Parliament, and this is what MPs and Peers voted for. It was the only purpose for the introduction of penalty notices for school absences. At no point during the passage of the Anti-Social Behaviour Act did any member on the government or opposition benches anticipate or suggest that penalty notices could or should be used to prevent parents taking their children out of school in order to go on holiday. Moreover, while penalty notices were clearly designed to deal with unauthorised absences, the legislation was also based on the notion that headteachers and other authorised individuals, would be able to use their professional judgement to determine when absences could be authorised and penalty notices applied. While headteachers retain the power to decide whether to issue a penalty notice, the change to the regulations introduced by the Education Secretary in 2013, removed the possibility for headteachers to use their professional judgement in decisions about authorising absence for term-time holidays and as a result changed the meaning of the Anti-Social Behaviour Act, by creating a criminal liability for all parents taking their children out of school to go on holiday. These changes, which were included in a piece of secondary legislation, and not therefore subject to detailed scrutiny or debate, appear to go some way beyond the technical amendments for which Statutory Instruments are designed, and represent a significant change to the principles underpinning part 3 of the Anti-Social Behaviour Act.

\section{Conclusions}

Parliament has never been given the opportunity to debate, and crucially vote, on the criminalisation of parents who take their children out of school for term-time holidays. Existing legislation clearly establishes a requirement that parents ensure their children attend school and creates a criminal liability for parents who fail to do so. The Anti-Social Behaviour Act made it easier for schools and local authorities to penalise parents who fail to meet this requirement. The creation of criminal liability and the application of penalty notices was, however, underpinned by a wideranging discretion on the part of headteachers to decide when to authorise absences from school. Under the 2006 regulations parents did not have a right to take their children out of school for up to ten days holiday in any school year, but headteachers did have the discretion to authorise absences 
on this basis. The change to the regulations in 2013 removed headteachers' discretion in this area and created an automatic criminal liability for parents taking their children out of school to go on holiday. This in itself is somewhat anomalous given that in other areas headteachers retain significant discretion in relation to the authorisation of absence. Moreover, by changing the regulations in this way, the Education Secretary significantly changed the meaning of the Anti-Social Behaviour Act. The widespread use of penalty notices against parents who take their children out of school for holidays was not what Parliament intended when penalty notices were extended to encompass school absences in 2003 and the manner in which the regulations were changed in 2013 provides a clear case for review. 


\section{References}

Allan, T.R.S. (2004), 'Legislative supremacy and legislative intent: a reply to Professor Craig' Oxford Journal of Legal Studies, 24, 4: 563-583.

Anti-Social Behaviour Act 2003, https://www.legislation.gov.uk/ukpga/2003/38/contents

Cawley, L. (2018), 'Parents fined $£ 24 \mathrm{~m}$ for children's truancy and term time holidays', BBC News online, 15 March, https://www.bbc.co.uk/news/uk-england-43254495

Coughlan, S. (2017) 'Term-time holiday dad loses court battle over school fine' BBC News online, 6 April 2017, https://www.bbc.co.uk/news/education-39504338

Byrne, P. (1976), 'Parliamentary control of delegated legislation', Parliamentary Affairs, 29, 4: 366377. https://doi.org/10.1093/oxfordjournals.pa.a054169

Craig, P.P. 'Legislative intent and legislative supremacy: a reply to Professor Allan' Oxford Journal of Legal Studies, 24, 4: 585-596.

Dağli, U.Y. (2018) Effect of increased instructional time on student achievement, Educational Review, DOI: 10.1080/00131911.2018.1441808

Education Act 1996, https://www.legislation.gov.uk/ukpga/1996/56/contents

Education (Pupil Registration) (England) Regulations 2006, SI 2006/1751, http://www.legislation.gov.uk/uksi/2006/1751/contents/made

Education (Penalty Notices) (England) Regulations 2007, SI 2007/1867, http://www.legislation.gov.uk/uksi/2007/1867/contents/made

Education (Pupil Registration) (England) (Amendment) Regulations 2013, SI 2013/756, http://www.legislation.gov.uk/uksi/2013/756/contents/made

Ekins, R. (2012), The Nature of Legislative Intent, Oxford: OUP.

Fox, R. and Korris, M. (2010), Making Better Law, London: The Hansard Society.

Fox R. and Blackwell, J. (2014), The devil is in the detail: Parliament and delegated legislation, London: The Hansard Society.

Griffiths, S. (2014a), 'Parents sue for term-time holidays' The Sunday Times, 25 May 2014.

Griffiths, S. (2014b), 'Court test for Gove's ban on holidays' The Sunday Times, 29 June 2014.

House of Lords Constitution Committee (2016), Delegated Legislation and Parliament: a response to the Strathclyde Review, London: The Stationery Office.

ITV News (2014), 'Term-time holiday prosecution abandoned' 8 September 2014, http://www.itv.com/news/anglia/story/2014-09-08/term-time-holiday-prosecution-abandoned/

Joint Committee on Statutory Instruments (2013), First Report of session 2013-14, https://publications.parliament.uk/pa/it201314/jtselect/itstatin/5/5.pdf 
Korris, M. (2011), 'Standing up for Scrutiny: How and why Parliament should make better law' Parliamentary Affairs, 64, 3: 564-574.

Laws, J. (2017), 'Statutory Interpretation - the myth of parliamentary intent' The Statute Law Society Renton Lecture, http://www.statutelawsociety.co.uk/wp-content/uploads/2017/11/The-Myth-ofParliamentary-Intent-text.pdf

Long, R. and Bolton, P. (2017), 'Holidays during school term-time (England), House of Commons Library Briefing Paper, No. 07950, 19 April, http://researchbriefings.files.parliament.uk/documents/CBP-7590/CBP-7590.pdf

Norton, P. (2013), Parliament and British Politics, $2^{\text {nd }}$ edition, Basingstoke: Palgrave.

Ward, (2017), 'Parking fines raise $f 820 \mathrm{~m}$ for local councils, up $10 \%$ on last year', The Daily Telegraph, 27 November 2017, https://www.telegraph.co.uk/news/2017/11/27/parking-fines-raise-820m-localcouncils-10-per-cent-last-year/

Parker, K. (2017), 'Teachers say parents should not be fined for term-time holidays', TES, 2 February 2017, https://www.tes.com/news/teachers-say-parents-should-not-be-fined-term-time-holidays

Rogers, R. and Walters, R. (2015), How Parliament Works, $7^{\text {th }}$ edition, Abingdon: Routledge.

Santry, C. (2016), 'Term-time holidays "do not harm primary test scores"', TES, 28 October 2016, https://www.tes.com/news/exclusive-term-time-holidays-do-not-harm-primary-test-scores

Supreme Court (2017), Judgment - Isle of Wight Council (Appellant) v Platt (Respondent), UKSC28, 6 April 2017, https://www.supremecourt.uk/cases/uksc-2016-0155.html

Transport Committee (2013), Local Authority Parking Enforcement - seventh report of session 201314, London: The Stationery Office.

https://publications.parliament.uk/pa/cm201314/cmselect/cmtran/118/118.pdf

YouGov (2014), 'Stop fines for term-time holidays', 27 February 2014,

https://yougov.co.uk/news/2014/02/27/stop-fines-holidays-term-time/

YouGov (2017), 'Support for term-time holidays increases', 4 April 2017,

https://yougov.co.uk/news/2017/04/04/support-term-time-holidays-increases/ 